JOURNAL OF SECURITY AND SUSTAINABILITY ISSUES

ISSN 2029-7017/ISSN 2029-7025 (online)

2020 Volume 10 Number (October)

http://doi.org/10.9770/jssi.2020.10.Oct(2)

Scopus

\title{
ARE PENSION OBLIGATIONS, PUBLIC OFFICE SALARIES AND INVESTMENT ON SOCIAL PROJECTS HURTING FISCAL SUSTAINABILITY? A PANEL DATA ANALYSIS OF ASEAN COUNTRIES
}

\author{
Obsatar Sinaga ${ }^{1}$, Djoko Roespinoedji² ${ }^{2}$ Jahanzaib Haider $^{3}$, Shahzadah Fahed Qureshi ${ }^{4^{*}}$

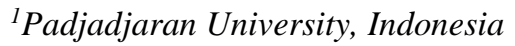 \\ ${ }^{2}$ Widyatama University, Indonesia \\ ${ }^{3}$ University of Kuala Lumpur, Malaysia \\ ${ }^{4}$ Bahauddin Zakariya University, Pakistan \\ 4*fahadqureshi@bzu.edu.pk (Corresponding author)
}

Received 15 December 2019; accepted 25 June 2020, published 30 October 2020

\begin{abstract}
Fiscal sustainability is the implementation of economic policies, which enables the stabilization of the net value of ratio of budget deficit. This value is usually expressed as a difference among the budget expense and the budget revenue. Pension obligations, office salaries, and investment on social projects are the aspects that are crucial for any government as well as the economy of a country and they might affect the fiscal sustainability of the country. In this context, the current study was designed in order to investigate the impact of pension obligations, office salaries and investment on social projects on fiscal sustainability in different ASEAN countries. In order to fulfill this aim, the researcher has collected data from 6 ASEAN countries i.e. Brunei, Cambodia, Indonesia, Laos, Thailand and Philippines for a period of 30 years. The major tests applied on the collected data include cross sectional dependence test, CIPS unit root test, LM Bootstrap cointegration test, AMG estimation and panel casualty test. The results obtained from these tests suggest that the impact of pension obligation, office salaries and investment in social projects on fiscal sustainability are found as significant. The theoretical and practical implications along with the limitations of the study have been discussed in the last of the study.
\end{abstract}

Keywords: Pension Obligations; Office; Salaries; Investment on Social Projects; Fiscal Sustainability; ASEAN; Panel

Reference to this paper should be made as follows: Sinaga, O., Roespinodji, D., Haider, J., Qureshi, F. Q. 2020. Are pension obligations, public office salaries and investment on social projects hurting fiscal sustainability? A panel data analysis of ASEAN countries. Journal of Security and Sustainability Issues, 10(Oct), 26-38. http://doi.org/10.9770/jssi.2020.10.Oct(2)

Jel Codes: O15, Q14

\section{Introduction}

The various advancements in the countries have given rise to variations in the economic balances among the economies of the world, ranging from the emerging to the emerged economies and within the countries (Baharumshah, Soon, \& Lau, 2017; İmrohoroğlu, Kitao, \& Yamada, 2019; Mazzoni, 2020; Vergara, 2020). Hence, the preservation of a balance in the macroeconomic conditions of any country is very important. The concept of macroeconomic balance is related to sustainability, which ensures continuity and sufficiency in the economy. Fiscal sustainability is related to the economic sustainability and is considered as a vital provision in the policy planning of the country's economy (Gümüş, 2019; Sasongko, Huruta \&Wardani, 2019; Feriyanto, 2020; Chen, Liu, Wang, \& Li, 2020; Čižo, Lavrinenko, \& Ignatjeva, 2020).

Hence, the concept of a country's fiscal sustainability shows the ability of its government by which they are able to finance the country's budget in a smooth manner without accumulating the public debt excessively in the long 
run or in short, it is the management of the financial responsibilities (Afonso \& Jalles, 2016; Chapman, 2008; Chen, Zhen, Dong, \& Xie, 2020; Krasnov, Okanova, Yeraliyeva, Kozhakhmetova, Karshalova, \& Luká, 2020; Rakhmetova, Kalkabayeva, Kurmanalina, Gusmanova, Serikova, \& Aimurzina, 2020). It is vital that the country's government must have solvency and it must be able to repay the debt in the specific point of future (Adams, Ferrarini, \& Park, 2010; Estrada, Park, \& Ramayandi, 2010). Technically speaking, the fiscal sustainability is derived from the overall budget deficit and government debt (Cahyadin \& Ratwianingsih, 2020). The conditions for a balanced budget are achieved through various means, the public debt being the most widely used one by a number of countries (Trehan \& Walsh, 1991; Villena, Gamboni, \& Tomaselli, 2018; Sabir \& Hussin, 2020). As shown in table 1 and figure 1 below, the values for Budget Deficit and the Government debt for the ASEAN countries are relatively high.

Table 1: Budget Balance of ASEAN countries (in relation to GDP expressed as \%)

\begin{tabular}{lll}
\hline Country & $\mathbf{2 0 2 0}$ & $\mathbf{2 0 1 9}$ \\
\hline Brunei & -26.58 & -10.46 \\
\hline Cambodia & -1.87 & -0.45 \\
\hline Indonesia & -5.01 & -2.23 \\
\hline Lao & -6.23 & -5.15 \\
\hline Malaysia & -4.2 & -3.18 \\
\hline Myanmar & -4.69 & -3.5 \\
\hline Philippines & -3.36 & -1.93 \\
\hline Singapore & -3.48 & 3.84 \\
\hline Thailand & -3.45 & 0.82 \\
\hline Vietnam & -5.15 & -3.3 \\
\hline
\end{tabular}

For the ASEAN nations, the management of the fiscal sustainability is a major macroeconomic issue for the government. These countries occupy a central position in a dynamic economic are of the globe. The financial performance of these countries has given rise to the 'Asian Miracle', which is a concept well known and wellinvestigated by the key economists and policymakers in the world (Bui, 2019; Hicklin, 1997). However, it is pertinent to note that the ASEAN economies had been badly affected by the financial crisis that took place in 1997- 1998 when the group of the ASEAN countries consisted of the four nations of Malaysia, Thailand, Indonesia and Philippines and later in 2007- 2008. The fiscal deficits in the ASEAN countries have been undergoing persistent variations. The reforms taken by these countries have enabled them to keep up with their fiscal sustainability (Lin \& Kueh, 2019; Raymundo, 2016; Iqbal, et al., 2020). Though their public debts and the fiscal deficits have been decreasing over a period of time, yet they are still considered to be high (Bui, 2019). Hence, this region is of immense significance for the study of fiscal sustainability. Many factors affect the fiscal sustainability, out of which the factors of pension obligation, public office salaries and investment on social projects will be considered for this study. 


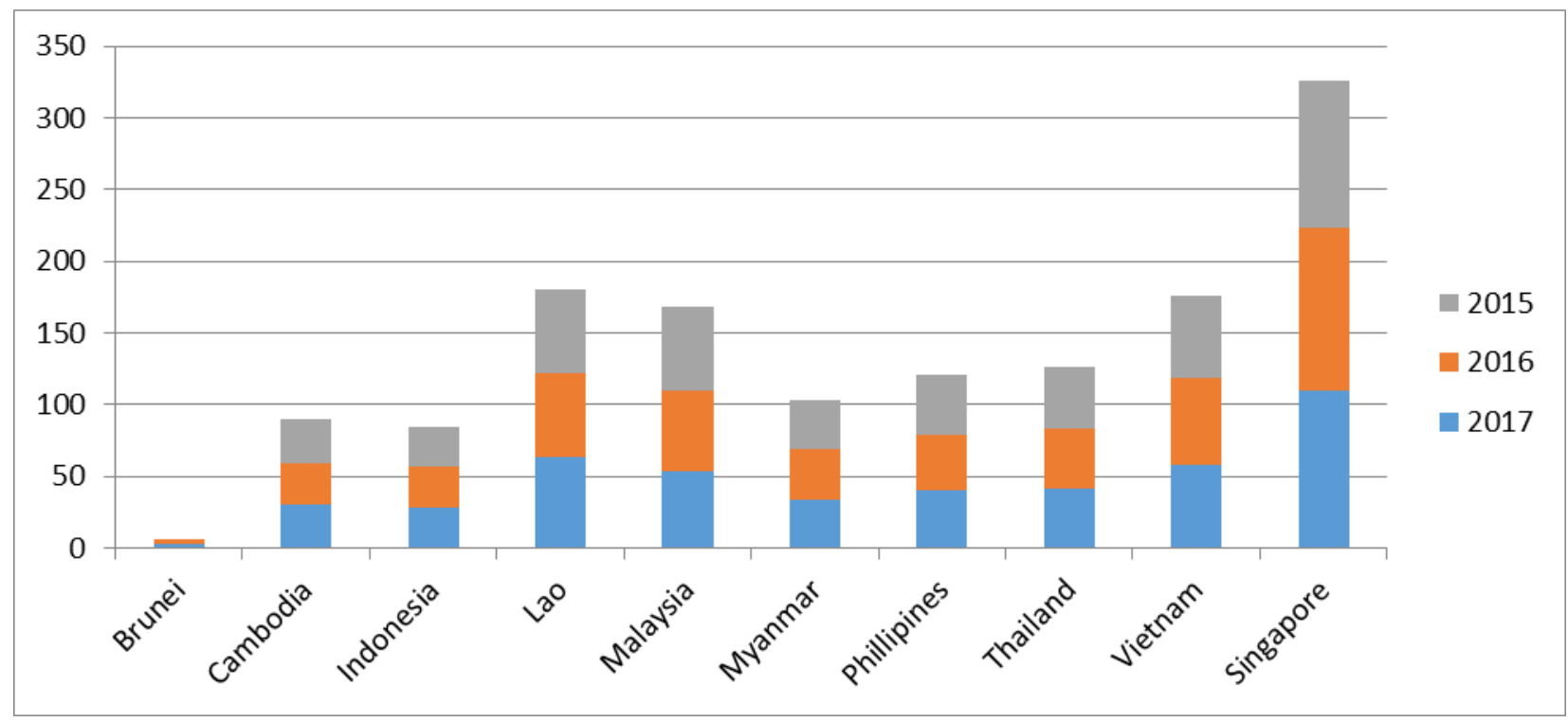

Figure 1: Government Debt of ASEAN countries (as percentage of GDP)

The main aim of this paper is to study the indicators that hurt the financial sustainability, specifically in the ASEAN countries using panel data techniques. The specific research objectives of this paper are:

- To analyze the impact of pension obligations on fiscal sustainability

- To analyze the impact of public office salaries on fiscal sustainability

- To analyze the impact of investments on social projects on fiscal sustainability

This paper has multiple contributions to theory and practice. This paper has contributed to the empirical literature on fiscal sustainability as it has attempted to investigate various factors affecting fiscal sustainability as suggested in the studies of (Gümüş, 2019; Lau \& Syn-Yee, 2018; Thuy, 2018) to further explore this notion in the South East Asian countries, which is a region attractive for economists. Practically, this study is beneficial to the policy makers and the economist as they can formulate and adjust their fiscal policies according to the requirement of the country using these results and can better understand how to adjust their fiscal indicators so that the budget and debt can be balanced. This study will help them adopt measures that can prove useful for boosting the economic growth and to support the socioeconomic development of the country.

\section{Literature review}

\subsection{Pension Obligations}

Scholars have defined fiscal sustainability as the implementation of economic policies which enables the stabilization of the net value of ratio of budget deficit (Buiter, 1983). This value is usually expressed as a difference among the budget expense and the budget revenue (Gümüş, 2019). (Blanchard, Chouraqui, Hagemann, $\&$ Sartor, 1991) has also given a comprehensive definition of fiscal sustainability as calculating the ratio of Public Debt/GNP and measures the ability of the government to pay off the loans using revenue from public. If the ratio of Public Debt/GDP remains consistent and stable compared to the economy's total demand, then this confirms the presence of fiscal sustainability in the country's economy. There are many factors that indicate the ongoing pressure and demand on the government and are affecting the sustainability of the country's budget and question the fiscal policies (Ali, Naveed, ul Hameed, \& Rizvi, 2018; Allen, 2005; Ha, 2016; Hamid, Shahid, Hameed, Amin, \& Mehmood, 2019). Pension obligation is considered as one such main component of the fiscal sustainability issues in the both the short and the long run for many countries of the world. The pension obligations in a system are measured using the ratios of pension payments to GDP in the short term and the 
JOURNAL OF SECURITY AND SUSTAINABILITY ISSUES

ISSN 2029-7017/ISSN 2029-7025 (online)

2020 Volume 10 Number (October)

http://doi.org/10.9770/jssi.2020.10.Oct(2)

present value of future pensions commitments in the long run. The economists have highlighted the significance of pension obligations and its impact on the fiscal sustainability, which has been linked to the expected ageing of the populations in the countries (Medaiskis et al., 2018; Chomik, Piggott, \& Yan, 2019; Kühner \& Chou, 2019). Scholars have pin pointed that these are likely to increase the government spending on the health care and the pensions of these people (Bird, 2006; Bryden, 1974; Chomik et al., 2019) with the rise in the aging population (Castro, Maria, Félix, \& Braz, 2017; Hong, Teng, \& Gan, 2019), especially in the ASEAN region (Chomik, McDonald, \& Piggott, 2016; Roy \& Le, 2018). Hence the countries are advised to restructure their pension systems or make adjustment for the pre- funding of their future payments so that the demanding pressures on the country's future budget can be lessened. In a study by the European Economy, the factors of pension, health care and long term care were investigated as challenges to the country's fiscal sustainability. The researchers found that the pension benefit ratio must be estimated and compared to the reference wage. If this ratio is very high then this means that the country has a generous pension system and vice versa. However, by reducing this ratio would mean that the generosity of pension system is being reduced that may lead to stabilization of the public pension expenditure and provide leverage to the government and the fiscal sustainability. For reducing the benefits, many factors, like the demographics, life expectancy on retirement and pension contributions can be shifted from being too generous to a point system or supplementary pension scheme, which can serve as a factor enhancing the fiscal sustainability (Carone \& Eckefeldt, 2014). In a similar paper by Asian development Bank Institution, the economies of the ASEAN and other emerging Asian countries was considered to be at threat from the ageing population in these countries and the related drastic rise in the pension expense by the government in the coming decades as biggest long-term fiscal challenge. IMF has estimated that these economies will face increase in the public spending owing to pensions and other services. This discussion shows that the pension obligations on the government can constraint the fiscal sustainability and the following hypothesis is made to depict this relationship.

H1: Pension Obligations are significantly related to fiscal sustainability

\subsection{Public Office Salaries}

In order to ensure sustainability, a country's primary balance of the public sector must be compatible and stabilized with the Public Debt/GDP ratio for ensuring sustainability. (Izquierdo \& Panizza, 2003) have related the fiscal sustainability to the sufficiency of the country in meeting the budget deficit. In addition to the pension obligations, the employment in the public sector and the associated wages and benefits also are demanding on the country's fiscal sustainability in the form of government expenditure (Dybczak \& Garcia-Escribano, 2019; Schiavo-Campo, de Tommaso, \& Mukherjee, 1997). A previously conducted World Bank policy study has shown that the government wage accounted for almost 5.4\% of the GDP. The rates of the wages for the local government accounted to nearly three-fourths of the wages of the central government wages and the accumulation of the civilian government wages absorbed about 9\% of the GDP as an average (Schiavo-Campo et al., 1997). This indicates that the salaries and wages of those working in the public offices had a huge effect on the government expenditure and the spending, which affects the fiscal sustainability. In another IMF working paper, it was reported that the growth in the bills for the wages of the public offices workers show how the government has expanded the measures and the activities for improving the social and the economic development, however this spending has a rigid effect on the fiscal sustainability at the same time (Mitchell, James, \& Wickham, 2019). This discussion proves the linkage of the public office salaries with the country's fiscal sustainability. Hence, the following hypothesis is made:

H2: Public Office Salaries are significantly related to fiscal sustainability

\subsection{Investment on Social Projects}

The funding of the social projects by the government deem a major threat to their capacity (Doorley, 2017; Garang, Issa, \& Ali, 2017) until they are subjected to a feasibility assessment (Chotia, 2017; Guilherme, Santos, Yamashita, \& Brandão, 2016). In UN meeting held in Brazil (2009), the investment on the projects aimed with 
JOURNAL OF SECURITY AND SUSTAINABILITY ISSUES

ISSN 2029-7017/ISSN 2029-7025 (online)

2020 Volume 10 Number (October)

http://doi.org/10.9770/jssi.2020.10.Oct(2)

social and economic causes was considered as a counter cyclical instrument that provides a challenge for the fiscal sustainability. The projects set for the social services, public welfare and the development of infrastructure influences the economic growth and productivity, but it is equally important that the countries analyze these investments to assess the benefit gained out of them in terms of the social profitability. A similar study has studied the impact of fiscal consolidation and the social investment for public and was found to have a significant effect on the government expenditure. Hence, the countries have been in the practice of reducing their investment to sustain and consolidate their fiscal indicators as it is easy to cut down the investment on such projects but this can have negative effect on the country's overall growth (Carranza, Daude, \& Melguizo, 2014). The development of the social infrastructure in sustainable ways is a major goal of the countries, especially those with low and medium levels of income as they are the ones who are struggling to build and enhance their country's infrastructure from the primary level. However, they are faced with the rise in the debt levels for building the said infrastructure, causing further decline in the growth rates and lesser productivity. This shows that investment in the social projects is the key to enhancing the growth and the productivity, which pushes the country into a vicious cycle of exacerbating the associated debt. It is a challenge for the countries to balance their fiscal budget constraints and the social goals. The World Bank has mandated the countries to develop measures for achieving the sustainable fiscal indicators and the social development. Hence, a precarious financial structuring is required weighing carefully the risks and the benefits of the investment in the social projects so that threat of increasing debt can be kept under control. A social project has the capacity to pass on a direct liability to the government. If projects are carried out without any proper analysis and planning, then costs will be unduly increased (Lu, Chao, \& Sheppard, 2019). These findings reveal that the investment on the social projects by the government significantly affect the fiscal sustainability of a country. Hence the following hypothesis is made to show this relationship:

H3: Investments on Social Projects are significantly related to fiscal sustainability.

\section{Data and Methodology}

\subsection{Data}

The current study is aimed at finding out and exploring the impact that is casted on the fiscal sustainability by pension obligations, office salaries and investment on social projects in different ASEAN countries. In order to meet this objective, the researcher has collected data from 6 ASEAN countries i.e. Brunei, Cambodia, Indonesia, Laos, Thailand and Philippines for a period of 30 years. As per the objectives of the study, the variables about which data has been collected include fiscal sustainability, pension obligations, office salaries and investment on social projects. Moreover, the researcher also has added two control variables among others which include per capita income and economic growth. The data has been collected from reliable data bases such as World Bank Development Indicators and Global Economy.

\subsection{Model Specification}

As far as the measurement units of the variables are concerned, fiscal sustainability is measured through debt to GDP ratio, pension obligation has been measured through US dollars. In the similar way, investment on social projects and office salaries has also been measured through US dollars. Per capita income, the first control variable has been measured by US dollars while economic growth has been taken as GDP growth of the country. The following regression model can be utilized for this study:

$$
F S_{i t}=\alpha+\beta_{1} P O_{i t}+\beta_{2} O S_{i t}+\beta_{3} I N_{i t}+\beta_{4} P C I_{i t}+\beta_{5} E G_{i t}+\varepsilon_{i t}
$$

In this equation, FS represents fiscal sustainability, PO represents pension obligations, OS represents office salaries, IN represents investment in social projects, PCI represents per capita income and EG represents economic growth. In the last, $\varepsilon_{i t}$ is the term that represents an error. 


\subsection{Estimation Procedure}

\subsubsection{Cross Sectional Dependence Test}

The first test that has been applied in the current study is cross sectional dependence test. The main reason behind using this test is that if the relationships that are present in the collected cross sectional data are not checked, it might result into the ambiguous outcomes (Breusch \& Pagan, 1980). The following model can be used for this test:

$$
C G_{B P}=T \sum_{i=1}^{N-1} \sum_{j=i+1}^{N} \widehat{P_{t j}^{2}}
$$

However, this model cannot be used if $\mathrm{N}$ is having a large value. This is the reason why an alternative model has been introduced which is given as follows:

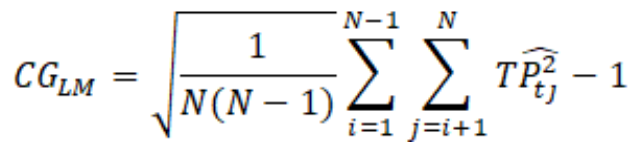

As far as the null and alternate hypotheses are concerned, the null hypothesis suggests that there is no cross sectional dependence while the alternate hypothesis suggests that there is cross sectional dependence. If the $p$ values of the null hypothesis is less that the significance then it can be rejected otherwise it is accepted. In addition to cross sectional dependence test, the researcher has also applied slope homogeneity test. The null hypothesis of this test indicates that the slopes are homogenous while the alternate hypothesis indicates that the statistics are having heterogeneous slopes (Hussain et al., 2020).

\subsubsection{Panel Unit Root Test}

The next test that has been applied by the researcher is panel unit root test with the purpose of finding out the stationarity of the variables. The unit root test that is used in the current study is CIPS by Im Pesaran Shin. The reason behind using this test is that it considers the cross sectional dependence (Pesaran \& Yamagata, 2008). The following equation can be used for this purpose:

$$
\Delta Y_{i, t}=a_{i}+b_{i} Y_{i, t-1}+c_{i} \bar{Y}_{t-1}+d_{i} \Delta \bar{Y}_{t}+e_{i, t}
$$

The version of the equation that considers the cross sectional dependence is as follows:

$$
C I P S=\frac{1}{N} \sum_{i=1}^{N} C A D F_{i}
$$

In this equation CADF represents the cross sectional version of ADF test (Pesaran, 2007). The null hypothesis of this test indicates that there is unit root in the data while the alternate hypothesis suggests that there is no unit root and the data is stationary.

\subsubsection{Panel Cointegration Test}

After unit root test, the next important test that is used in the current study is panel cointegration test so that the presence of any cointegrating relationship between the variables of the study can be checked. The cointegration test applied in this study is Westerlund and Edgerton bootstrap LM panel cointegration test. The benefit of this test is that is also considers the cross sectional dependence of the data (Westerlund \& Edgerton, 2007). The following equation can be used for this test:

$$
L M_{N}^{+}=\frac{1}{N T^{2}} \sum_{i=1}^{N} \sum_{t=1}^{T} \widehat{w_{i}^{-2}} e_{i t}^{2}
$$

The null hypothesis of this test suggests that cointegration is present in the regression model while the alternate hypothesis suggests that cointegration is not present in the regression model. The rejection of the null hypothesis 
JOURNAL OF SECURITY AND SUSTAINABILITY ISSUES

ISSN 2029-7017/ISSN 2029-7025 (online)

2020 Volume 10 Number (October)

http://doi.org/10.9770/jssi.2020.10.Oct(2)

is based on the $\mathrm{p}$ value, if it is less than the significant value, then null hypothesis will be rejected and otherwise it will be accepted. After cointegration test, the coefficients of the variables have been estimated by using AMG estimation procedure, which also has the benefit of considering the cross sectional dependence.

\subsubsection{Panel Casualty Test}

The last test applied by the researcher is panel casualty test so that the casual relationships among the variables of the study can be estimated. The casualty test that have been used in this study i.e. Kónya casualty test is better than the other casualty tests because it assumes that there is no issue regarding the cross sectional dependence. In addition, it also assumes that the casualty tests have been performed on the series that have unit root and do not have cointegrating relationships. Moreover, it is beneficial because other pre requisite tests are not needed to be performed (Kónya, 2006). The following equation can be used for this test:

$$
F S_{N, t}=\alpha_{2, N}+\sum_{i=1}^{l y 2} \beta_{2, N, i} O S_{N, t-1}+\sum_{i=1}^{l x 2} \delta_{2, N, i} F S_{N, t-1}+e_{2, N, t}
$$

\section{Results and Analysis}

\subsection{Results of Cross Sectional Dependence Test}

The results of cross sectional dependence as well as slope homogeneity tests have been reported in the table 2 . As per the results, it can be seen that in case of $C_{B \mathrm{BP}}, \mathrm{CD}_{\mathrm{LM}}$ and $\mathrm{CD}$, the values for all the variables have rejected the null hypothesis of no cross sectional dependence. Based on these results, it can be stated that all the variables of the study are having cross sectional dependence. As far as slope homogeneity results are concerned, it can be seen in in case of both delta and adjusted delta, the $\mathrm{p}$ value is less than the significant value and thus the null hypothesis have also been rejected in this test. In other words, it can be stated that the unit coefficients of the study are heterogeneous. The results of these tests make the data qualified to be entered the next steps of the estimation.

Table 2: Cross-Section Dependence and Slope Homogeneity Tests

\begin{tabular}{llll}
\hline Variable & $C D_{B P}$ & $C D_{L M}$ & $C D$ \\
\hline PO & $136.388^{*}$ & $78.498^{*}$ & $23.397^{*}$ \\
OS & $177.397^{*}$ & $38.984^{*}$ & $21.498^{*}$ \\
IN & $123.374^{*}$ & $98.489^{*}$ & $24.487^{*}$ \\
FS & $198.498^{*}$ & $68.494^{*}$ & $43.763^{*}$ \\
PCI & $123.498^{*}$ & $98.498^{*}$ & $32.498^{*}$ \\
EG & $103.488^{*}$ & $78.398^{*}$ & $23.398^{*}$ \\
\hline Slope Homogeneity Tests Results & & \\
\hline Tests & LM Statistics & t-value & P-Value \\
Delta & $33.49^{*}$ & 3.367 & .000 \\
Adj Delta & $27.39^{*}$ & 2.387 & .000 \\
\hline
\end{tabular}

\subsection{Results of Panel Unit Root Test}

The results obtained by the application of CIPS unit root test by the researcher have been declared in the table 3 . According to these results, it can be seen that in the level series, all the variables have not rejected the null hypothesis of unit root. Pension obligations and per capita income have accepted the null hypothesis. Therefore, the researcher has first differenced all the variables and has checked the results of CIPS test. In this series, it can be seen in the table that all the variables have rejected the null hypothesis and it can be stated that the data is stationary and there is no unit root in the model (Bilan et al., 2020) 
JOURNAL OF SECURITY AND SUSTAINABILITY ISSUES

ISSN 2029-7017/ISSN 2029-7025 (online)

2020 Volume 10 Number (October)

http://doi.org/10.9770/jssi.2020.10.Oct(2)

Table 3: CIPS Panel Unit Root Test

\begin{tabular}{lll}
\hline Variable & At Level & First Difference \\
\hline PO & -2.1873 & $-5.2863^{* *}$ \\
OS & $-4.3884 *$ & $-6.3484 * *$ \\
IN & $-2.8754 *$ & $-10.2394^{* * *}$ \\
FS & $-3.3884 *$ & $-8.2404^{* *}$ \\
PCI & -4.8498 & $-8.9763 * * *$ \\
EG & $-2.2884 *$ & $-7.8283^{* *}$ \\
\hline
\end{tabular}

\subsection{Results of Panel Cointegration Test}

After panel unit root test results, the results of panel cointegration test (LM bootstrap) have been presented in the table 4. As per this table, it can be seen that the $\mathrm{p}$ values in both cases i.e. constant and constant plus trend is less than the significant value and thus the null hypothesis of no cointegration has been rejected by the variables of the study. In other words, it can be stated that all the variables are having long run relationship or cointegration with each other in the study.

Table 4: LM Bootstrap Panel Cointegration Test

\begin{tabular}{lll}
\hline Conditions & LM statistics & Bootstrap p-value \\
\hline Constant & -3.387 & 0.876 \\
Constant + Trend & 3.497 & 0.885 \\
\hline
\end{tabular}

The AMG estimation results are very significant for the study and have been presented in the table 5. According to these results, it can be seen that the impact of pension obligation on fiscal sustainability is positive and significant for all the countries of the panel. In the same way, the impact casted by office salaries on fiscal sustainability is also significant and positive for all countries except for Indonesia, for which the impact of office salaries is positive but insignificant. As far as investment in social projects is concerned, its impact on fiscal sustainability is positive and significant for all the countries of the panel. In case of the control variable per capita income, its impact on fiscal sustainability for all countries is also significant and positive but for Cambodia, its impact is not found as significant. In the last, there is another control variable i.e. economic growth, the impact of which on fiscal sustainability for all the countries is positive and significant.

Table 5: AMG Estimation

\begin{tabular}{llllll}
\hline Countries & PO & OS & IN & PCI & EG \\
\hline Brunei & $0.212^{* *}$ & $0.127^{* *}$ & $0.200^{* *}$ & $0.176^{* *}$ & $0.123^{* *}$ \\
Cambodia & $0.133^{*}$ & $0.188^{*}$ & $0.187^{*}$ & 0.012 & $0.208^{* *}$ \\
Indonesia & $0.187^{*}$ & 0.083 & $0.193^{* *}$ & $0.103^{*}$ & $0.189^{*}$ \\
Laos & $1.317^{* *}$ & $0.121^{* *}$ & $0.203^{* *}$ & $0.197^{* *}$ & $0.186^{*}$ \\
Thailand & $0.278^{* *}$ & $0.202^{* *}$ & $0.233^{* *}$ & $0.132^{* *}$ & $0.205^{*}$ \\
Philippines & $0.129^{* *}$ & $0.123^{* *}$ & $0.139^{* * *}$ & $0.123^{* *}$ & $0.195^{* *}$ \\
Panel & $0.237^{* *}$ & $0.302^{* *}$ & $0.386^{* * *}$ & $0.254^{* * *}$ & $0.259^{* *}$ \\
\hline
\end{tabular}

\subsection{Results of Panel Casualty Test}

The results of the last test of the study applied by the researcher i.e. panel casualty test have been reported in table 6. Pair wise results for casualty between all the variables have been presented in the table. It is clear from the table that there is bidirectional casualty between office salaries and fiscal sustainability. In the same way, pension obligations and fiscal sustainability also have bidirectional casualty running between them. However, in case of investment in social projects and fiscal sustainability, there is unidirectional casualty running from IN to FS. As far as office salaries and pension obligation are concerned, they are also having bidirectional casualty running between them which is the case also observed in case of pension obligation and investment on social projects. 
JOURNAL OF SECURITY AND SUSTAINABILITY ISSUES

ISSN 2029-7017/ISSN 2029-7025 (online)

2020 Volume 10 Number (October)

http://doi.org/10.9770/jssi.2020.10.Oct(2)

However, there is unidirectional casualty found between investment in social projects and office salaries running from OS to IN.

Table 6: Kónya Panel Causality Test

\begin{tabular}{lll}
\hline Null Hypothesis: & F-Statistic & Prob. \\
\hline OS does not Granger Cause FS & 4.33266 & 0.0099 \\
FS does not Granger Cause OS & 6.31730 & 0.0091 \\
PO does not Granger Cause FS & 4.72063 & 0.0017 \\
FS does not Granger Cause PO & 5.79076 & 0.0046 \\
IN does not Granger Cause FS & 5.05351 & 0.0087 \\
FS does not Granger Cause IN & 1.18308 & 0.3120 \\
PO does not Granger Cause OS & 7.37410 & 0.0092 \\
OS does not Granger Cause PO & 4.76630 & 0.0083 \\
IN does not Granger Cause OS & 0.68184 & 0.5088 \\
OS does not Granger Cause IN & 7.77580 & 0.0064 \\
IN does not Granger Cause PO & 9.09102 & 0.0007 \\
PO does not Granger Cause IN & 6.88280 & 0.0018 \\
\hline
\end{tabular}

\section{Discussion and Conclusion}

\subsection{Discussion}

The current study was designed in order to investigate the impact of pension obligations, office salaries and investment on social projects on fiscal sustainability in different ASEAN countries. In this regard, the first hypothesis was that pension obligation has significant impact on fiscal sustainability. This hypothesis has been accepted as per the results obtained in the study. When the pension systems of the countries are developed and adjusted by the governments, it provides sustainability to the macroeconomic conditions and ultimately results in fiscal sustainability. The similar results have been obtained in a related study conducted in the past (Baharumshah et al., 2017). The second hypothesis was that office salaries have significant impact on fiscal sustainability, which has also been accepted for all the countries except for Indonesia where the impact was found as insignificant. If the office salaries are balanced as per the GDP of the country, it improves the fiscal sustainability of the country. The last literature supports this result (Biondi \& Boisseau-Sierra, 2017). The last hypothesis was that investment in social projects has significant impact on fiscal sustainability. This hypothesis, as per the results, has also been accepted as its impact has been found significant in case of all the countries included in the panel. When the governments of different countries give attention to the social projects and infrastructure of the country in a balanced way, it provides fiscal sustainability to the economy of those countries. This result is in concordance with the similar studies conducted in the past. Apart from these three variables, two control variables were also taken i.e. per capita income and economic growth. The results have shown that per capita income has significant impact on fiscal sustainability for all the countries except for Cambodia while economic growth is found to cast significant impact on fiscal sustainability for all countries. These results comply with the past studies of similar context (Wang, Su, Li, \& Ponce, 2019).

\subsection{Conclusion}

This study was conducted with the aim to explore the impact of pension obligations, office salaries and investment on social projects on fiscal sustainability in different ASEAN countries. The researcher collected panel data from six ASEAN countries for 30 years about the respective variables and applied various estimation techniques and approaches on the collected data to obtain the results. According to the results, as the impact of pension obligation, office salaries and investment in social projects on fiscal sustainability has been found as significant, it can be concluded that the countries that have been included in the panel of the current study must 
JOURNAL OF SECURITY AND SUSTAINABILITY ISSUES

ISSN 2029-7017/ISSN 2029-7025 (online)

2020 Volume 10 Number (October)

http://doi.org/10.9770/jssi.2020.10.Oct(2)

give attention and devise policies to improve the conditions of pension obligations and office salaries and must also promote the investment in various social projects so that the fiscal sustainability might be enhanced.

\subsection{Implication and Limitations}

The theoretical implication of the current study is that it will provide a good amount of literature about the aspects such as pension obligations, office salaries, and investment on social projects and fiscal sustainability, which might be useful for the researchers for their studies. The practical implication of this study is that it will provide information to governments of the selected ASEAN countries about how they can attain fiscal sustainability in their economy. They will also be able to devise policies and regulations that will improve the systems of pension obligations, office salaries, and investment on social projects.

The most important limitations of the current study include small sample size; focus only on few ASEAN countries and applying selective estimation techniques. The other researcher might consider increasing the sample size and they must consider other countries or group of countries as well to conduct this study.

\section{References}

Adams, C., Ferrarini, B., \& Park, D. (2010). Fiscal sustainability in developing Asia. Asian Development Bank Economics Working Paper Series(205). https://papers.ssrn.com/sol3/papers.cfm?abstract_id=1751833

Afonso, A., \& Jalles, J. T. (2016). The elusive character of fiscal sustainability. Applied Economics, 48(28), 2651-2664.

https://www.tandfonline.com/doi/abs/10.1080/00036846.2015.1128074

Ali, G., Naveed, F., ul Hameed, W., \& Rizvi, T. (2018). The Effect of Task Illegitimacy on the Wellness of Employees. UCP Management Review (UCPMR), 2(2), 5-20. https://ucpmr1.ucp.edu.pk/index.php/UCPMR/article/view/24

Allen, S. (2005). Sustainable Budget Policy: Concepts and Approaches. OECD Journal on Budgeting.

Baharumshah, A. Z., Soon, S.-V., \& Lau, E. (2017). Fiscal sustainability in an emerging market economy: When does public debt turn bad? Journal of Policy Modeling, 39(1), 99-113. https://www.sciencedirect.com/science/article/pii/S0161893816300990

Biondi, Y., \& Boisseau-Sierra, M. (2017). Pension obligations in the European union: A case study for accounting policy. Accounting, Economics, and Law: A Convivium, 7(3). https://www.degruyter.com/view/journals/ael/7/3/article-20170027.xml

Bird, R. M. (2006). Fiscal Flows, Fiscal Balance, and Fiscal Sustainability. Perspectives on fiscal federalism, 81-97.

Bilan, Y., Hussain, H.I., Kot, S., Haseeb, M. and Jermisittiparsert, K. (2020) Sustainability and Economic Performance: Role of Organizational Learning and Innovation, Engineering Economics, 31 (1), 93-103. https://doi.org/10.5755/j01.ee.31.1.24045

Blanchard, O. J., Chouraqui, J.-C., Hagemann, R., \& Sartor, N. (1991). The sustainability of fiscal policy: New answers to an old question. NBER Working Paper (R1547). https://papers.ssrn.com/sol3/papers.cfm?abstract_id=227461

Breusch, T. S., \& Pagan, A. R. (1980). The Lagrange multiplier test and its applications to model specification in econometrics. The Review of Economic Studies, 47(1), 239-253.

Bryden, K. (1974). Old age pensions and policy-making in Canada: McGill-Queen's Press-MQUP.

Bui, D.-T. (2019). Fiscal sustainability in developing Asia-new evidence from panel correlated common effect model. Journal of Asian Business and Economic Studies. https://www.emerald.com/insight/content/doi/10.1108/JABES-01-20190001/full/html?utm_source=TrendMD\&utm_medium=cpc\&utm_campaign=Journal_of_Asian_Business_and_Economic_Studies_TrendM $\underline{\mathrm{D} O}$

Buiter, W. H. (1983). Measurement of the public sector deficit and its implications for policy evaluation and design. Staff Papers, 30(2), 306-349. 
JOURNAL OF SECURITY AND SUSTAINABILITY ISSUES

ISSN 2029-7017/ISSN 2029-7025 (online)

2020 Volume 10 Number (October)

http://doi.org/10.9770/jssi.2020.10.Oct(2)

Cahyadin, M., \& Ratwianingsih, L. (2020). External Debt, Exchange Rate, and Unemployment in Selected ASEAN Countries. Jurnal Ekonomi \& Studi Pembangunan, 21(1), 16-36. https://borang.umy.ac.id/index.php/esp/article/view/8055

Carone, G., \& Eckefeldt, P. (2014). Identifying fiscal sustainability challenges in the areas of pension, health care and long-term care policies: Publications Office.

Carranza, L., Daude, C., \& Melguizo, Á. (2014). Public infrastructure investment and fiscal sustainability in Latin America: incompatible goals? Journal of Economic Studies. https://www.emerald.com/insight/content/doi/10.1108/JES-03-2012-0036/full/html

Castro, G., Maria, J. R., Félix, R. M., \& Braz, C. R. (2017). Aging and fiscal sustainability in a small Euro area economy. Macroeconomic Dynamics, 21(7), 1673-1705.

Chapman, J. I. (2008). State and local fiscal sustainability: The challenges. Public Administration Review, 68, S115-S131.

https://onlinelibrary.wiley.com/doi/abs/10.1111/j.1540-6210.2008.00983.x

Chomik, R., McDonald, P., \& Piggott, J. (2016). Population ageing in Asia and the Pacific: Dependency metrics for policy. The Journal of the Economics of Ageing, 8, 5-18. https://www.sciencedirect.com/science/article/pii/S2212828X15300177

Chomik, R., Piggott, J., \& Yan, S. (2019). Aging, fiscal sustainability, and adequacy of social security systems. Asian Development Bank Institute (ed.) Aging Societies: Policies and Perspectives. Tokyo: Asian Development Bank Institute, 52-64.

Chen, J., Liu, J., Wang, Y., \& Li, P. (2020). Behavioral psychology analysis of individual decision, strategic interaction and climate governance. Revista Argentina de Clinica Psicologica, 29(1), 423-434. https://doi.org/10.24205/03276716.2020.58

Chen, L., Zhen, J., Dong, K., \& Xie, Z. (2020). Effects of sanction on the mentality of information security policy compliance. Revista Argentina de Clinica Psicologica, 29(1), 39-49. https://doi.org/10.24205/03276716.2020.6

Chotia, V. (2017). Public Infrastructure Investment, Economic Growth and Fiscal Sustainability in India: An Empirical Analysis. BITS Pilani.

Čižo, E., Lavrinenko, O., Ignatjeva, S. (2020). Analysis of the relationship between financial development and economic growth in the EU countries. Insights into Regional Development, 2(3), 645-660. https://doi.org/10.9770/IRD.2020.2.3(3)

Doorley, K. (2017). Fiscal Sustainability and Demographic Change. ESRI Research Bulletin 2017/07. http://aei.pitt.edu/101993/

Dybczak, M. K., \& Garcia-Escribano, M. M. (2019). Fiscal Implications of Government Wage Bill Spending: International Monetary Fund.

Estrada, G. B., Park, D., \& Ramayandi, A. (2010). Financial development and economic growth in developing Asia. Asian Development Bank Economics Working Paper (233). https://papers.ssrn.com/sol3/papers.cfm?abstract_id=1751833

Feriyanto, N. (2020). Determinants of The Indonesia's Current Account Balance: An Error Corection Model Approcah. Entrepreneurship and Sustainability Issues, 7(4), 3410-3425. http://doi.org/10.9770/jesi.2020.7.4(55)

Garang, J. A., Issa, A., \& Ali, A. (2017). Assessing Transition to Stability, Fiscal Sustainability and Provision of Peace Dividend in South Sudan. https://www.africaportal.org/publications/assessing-transition-stability-fiscal-sustainability-and-provision-peace-dividend-south$\underline{\text { sudan/ }}$

Guilherme, d. A., Santos, F. P., Yamashita, Y., \& Brandão, R. (2016). Fiscal Feasibility Assessment Applied to Transport Infrastructure Projects. Paper presented at the CIT2016: 12. Congress of Transport Engineering, 7-9 June 2016, Valencia (Spain).

Gümüş, E. (2019). Examination of Financial Sustainability in Turkey (2002-2018). Journal of Finance, 7(2), 37-46.

Hamid, S. N. A., Shahid, M. N., Hameed, W. U., Amin, M., \& Mehmood, S. (2019). Antecedents Of Job Stress And Its Impact On Nurse's Job Satisfaction And Turnover Intention In Public And Private Hospitals Of Punjab Pakistan. International Journal of Scientific \& Technology Research, 8(10), 129-137.

Hicklin, J. (1997). Macroeconomic issues facing ASEAN countries: International Monetary Fund. 
JOURNAL OF SECURITY AND SUSTAINABILITY ISSUES

ISSN 2029-7017/ISSN 2029-7025 (online)

2020 Volume 10 Number (October)

http://doi.org/10.9770/jssi.2020.10.Oct(2)

Hong, P. K., Teng, Y. M., \& Gan, G. L. (2019). Ageing in Asia: Contemporary Trends and Policy Issues (Vol. 1): World Scientific.

Hussain, H.I., Slusarczyk, B., Kamarudin, F., Thaker, H.M.T., Szczepańska-Woszczyna, K. (2020). An Investigation of an Adaptive Neuro-Fuzzy Inference System to Predict the Relationship among Energy Intensity, Globalization, and Financial Development in Major ASEAN Economies. Energies, 13, 850. https://doi.org/10.3390/en13040850

İmrohoroğlu, S., Kitao, S., \& Yamada, T. (2019). Fiscal sustainability in Japan: What to tackle? The Journal of the Economics of Ageing, $14,100205$.

Izquierdo, A., \& Panizza, U. (2003). Fiscal sustainability: Issues for emerging market countries: Egyptian Center for Economic Studies.

Iqbal, A., Farooqi, M. T. K., \& Ahmed, S. (2020). Endangered Species In Teaching Profession: Perceptions Of Male And Female Prospective Teachers About Teaching Career. Hamdard Islamicus, 43(3), 52-67.

Kónya, L. (2006). Exports and growth: Granger causality analysis on OECD countries with a panel data approach. Economic Modelling, 23(6), 978-992. https://www.sciencedirect.com/science/article/abs/pii/S0264999306000496

Krasnov, A., Okanova, A., Yeraliyeva, Y., Kozhakhmetova, M., Karshalova, A., Luká, M.A. (2020). Development of the financial policy of the Eurasian economic union countries: tax harmonization. Entrepreneurship and Sustainability Issues, 8(1), 138-149. http://doi.org/10.9770/jesi.2020.8.1(9)

Kühner, S., \& Chou, K. L. (2019). Poverty alleviation, coverage and fiscal sustainability: Investigating the effect of a new social pension in Hong Kong. International Journal of Social Welfare, 28(1), 89-99.

Lau, E., \& Syn-Yee, A. L. (2018). Estimating fiscal reaction functions in Malaysia, Thailand, and the Philippines. Jurnal Ekonomi Malaysia, 52(1), 67-76.

Lin, S. X., \& Kueh, J. (2019). Twin Deficits and Debts in 6 ASEAN Countries: A Panel Approach. International Journal of Academic Research In Business And Social Sciences, 9(7), 550-559.

Mazzoni, F. (2020). Circular economy and eco-innovation in Italian industrial clusters. Best practices from Prato textile cluster. Insights into Regional Development, 2(3), 661-676. https://doi.org/10.9770/IRD.2020.2.3(4)

Medaiskis, T., Gudaitis, T., Mečkovski, J. (2018). Second pension pillar participants' behaviour: the Lithuanian case. Entrepreneurship and Sustainability Issues, 6(2), 620-635. http://doi.org/10.9770/jesi.2018.6.2(11)

Mitchell, M. A. W., James, R., \& Wickham, A. M. (2019). Government Wage Bill Management and Civil Service Reform in the Eastern Caribbean Currency Union: International Monetary Fund.

Pesaran, M. H. (2007). A simple panel unit root test in the presence of cross-section dependence. Journal of applied Econometrics, 22(2), 265-312. https://onlinelibrary.wiley.com/doi/full/10.1002/jae.951

Pesaran, M. H., \& Yamagata, T. (2008). Testing slope homogeneity in large panels. Journal of econometrics, 142(1), 50-93.

Rakhmetova, A., Kalkabayeva, G., Kurmanalina, A., Gusmanova, Zh., Serikova, G., Aimurzina, B. (2020). Financial-credit and innovative economic sectors: evaluation of macroeconomic effects of regulation and interaction sectors. Entrepreneurship and Sustainability Issues, 8(1), 1224-1237. http://doi.org/10.9770/jesi.2020.8.1(82)

Raymundo, R. B. (2016). Fiscal Sustainability and Sovereignty Issues under an Asean Economic Union. Paper presented at the DSLU Research Congress, De La Salle University, Manila, Philippines, March.

Roy, A., \& Le, A. (2018). Asia at A Crossroads: Demographics, Economics \& Investment. 85-98. https://doi.org/10.9770/ird.2019.1.2(1)

Sasongko, G., Huruta, A.D., Wardani, A. (2019). Does the Wagner's Law exist in a strategic national area? An evidence from Kedungsepur - Indonesia. Insights into Regional Development, 1(2), 99-117. https://doi.org/10.9770/ird.2019.1.2(2)

Schiavo-Campo, S., de Tommaso, G., \& Mukherjee, A. (1997). Government employment and pay in global perspective: a selective synthesis of international facts, policies and experience. World Bank Policy Research Working Paper 1806. 1997. 
JOURNAL OF SECURITY AND SUSTAINABILITY ISSUES

ISSN 2029-7017/ISSN 2029-7025 (online)

2020 Volume 10 Number (October)

http://doi.org/10.9770/jssi.2020.10.Oct(2)

Sabir, F., \& Hussin, F. (2020). Leadership Styles, Motivation Factors And Performance Appraisal As Predictor of Teachers'job Satisfaction. Hamdard Islamicus, 43(3), 42-51.

Trehan, B., \& Walsh, C. E. (1991). Testing intertemporal budget constraints: Theory and applications to US federal budget and current account deficits. Journal of Money, Credit and banking, 23(2), 206-223. https://www.jstor.org/stable/1992777

Vergara, R. M. A. (2020). Aproximación metodológica a la evaluación cuantitativa de la capacidad de carga del suelo urbano: Bogotá (Colombia 2015). Cuadernos de Economía, 43(123). https://doi.org/10.32826/cude.v43i123.142

Villena, M. G., Gamboni, C., \& Tomaselli, A. (2018). Fiscal sustainability and the cyclically adjusted balance policy: methodology and analysis for Chile. CEPAL Review.

Wang, Q., Su, M., Li, R., \& Ponce, P. (2019). The effects of energy prices, urbanization and economic growth on energy consumption per

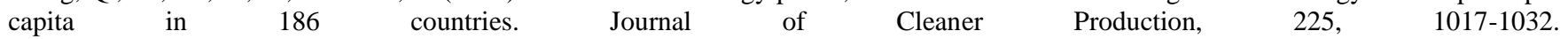
https://www.sciencedirect.com/science/article/abs/pii/S0959652619310765

Westerlund, J., \& Edgerton, D. L. (2007). A panel bootstrap cointegration test. Economics Letters, 97(3), 185-190.

\section{Obsatar SINAGA}

Prof. Dr. H. Obsatar Sinaga is currently the Rector of University of Widyatama, Bandung in Indonesia. He was also previously awarded the best researcher award by the government of Indonesia.

ORCID ID: https://orcid.org/0000-0002-7829-3902

\section{Djoko ROESPINOEDJI}

Djoko Roespinoedji is the Chairman of the Widyatama Foundation and is also the Deputy Chancellor of University of Widyatama, Bandung in Indonesia.

ORCID ID: https://orcid.org/0000-0001-8083-6104

Jahanzaib HAIDER

Haider is a Ph.D Student in UniKL Business School, University of Kuala Lumpur, Kuala Lumpur, Malaysia ORCID ID: https://orcid.org/0000-0002-0341-5354

\section{Shahzadah Fahed QURESHI}

Dr. Qureshi is Assistant Professor of Economics at Institute of Banking \& Finance, Bahauddin Zakariya University Multan, Pakistan.

ORCID ID: https://orcid.org/0000-0002-3668-7022

This work is licensed under the Creative Commons Attribution International License (CC BY).

http://creativecommons.org/licenses/by/4.0/

(c) (i) Open Access 